\title{
Dance and Movement Psychotherapy - description of the method and group sessions in General Psychiatric Ward
}

\author{
Psychoterapia Tańcem i Ruchem - opis metody oraz sesji grupowych \\ w Oddziale Ogólnopsychiatrycznym \\ Ewelina Drzał' ${ }^{1}$ ABDEF, https://orcid.org/0000-0003-1247-1558, \\ Marcin Łata $^{2} \mathrm{E}$,
}

${ }^{1}$ I Department of Psychiatry, Psychotherapy and Early Intervention, Medical University of Lublin, Poland ${ }^{2}$ I Department of Psychiatry, Psychotherapy and Early Intervention, Independent Public Clinical Hospital no 1,

Lublin, Poland

\begin{abstract}
Introduction: Dance and movement psychotherapy is a psychotherapeutic approach, which assumes that expressive movement can reflect the emotional state of the moving person. It is a method in which movement is supposed to lead to personal integration and development, and the psychotherapist is supposed to create conditions in which emotions can be safely expressed and transmitted, and can meet with acceptance.

Material and method: The aim of this study is to describe a case series of patients treated at the General Psychiatric Ward who participated in group sessions of dance and movement psychotherapy (DMT), and to analyse the impact of psychotherapy on their treatment process. In 2019, 12 patients of the General Psychiatric Ward were included in dance and movement psychotherapy (DMT) sessions. The sessions took place once a week from October 2019 to December 2019 and lasted $1 \mathrm{~h}$ and 10 min. A common element in movement that could be observed in most people in this group was tense shoulders and free forearms and hands. In addition, it was possible to observe in the group members compact flow, free time, multidirectionality, light weight according to the LMA System. Under the influence of the applied interventions it was possible to observe how the bodies of individual group members relax and their chests open. It was also observed how the participants activated their deep abdominal muscles and settled into the therapeutic space. At the same time it was apparent how the patients became attentive to their bodies and movement, which, in turn, translated into their sense of confidence and reduction in anxiety and tension.

Discussion: The main problem of semi-open groups is the impaired ability to integrate patients and the difficulty in finding trust and a sense of security. In addition, resistance to attachment naturally arises in group members. Patients do not have the opportunity to experience all stages of the development of the therapy group, especially the last one, the phase of ending psychotherapy. Nevertheless, the semi-open therapy group seems to have some advantages and some problems are highlighted, so that psychotherapeutic work on them can be deepened.

Conclusions: Although conducting a group process in a semi-open community is not a comfortable situation for the psychotherapist and the patients due to the difficulty of finding a sense of security and the naturally occurring resistance to attachment, the sessions seem to be very helpful in integrating the patients' community and in dealing with the inner tensions of each member.
\end{abstract}

Keywords: psychotherapy, DMT, LMA, therapy group

\section{Streszczenie}

Wstęp: Psychoterapia tańcem i ruchem to nurt psychoterapeutyczny, który zakłada, że ekspresyjny ruch może odzwierciedlać stan emocjonalny poruszającej się osoby. Jest to metoda, w której ruch ma prowadzić do osobistej integracji i rozwoju, a psychoterapeuta ma stworzyć warunki, w których emocje mogą być w bezpieczny sposób wyrażone i przekazane oraz mogą się spotkać z akceptacją.

Materiał i metoda: W roku 201912 pacjentów Oddziału Ogólnopsychiatrycznego było objętych sesjami psychoterapii tańcem i ruchem (DMT). Sesje odbywały się raz w tygodniu od października 2019 r. do grudnia 2019 r. i trwały 1 h i 10 min. 
Dyskusja: Wspólny element w ruchu, który można było zaobserwować u większości osób w tej grupie to spięte, ramiona oraz swobodne przedramiona i dłonie. Dodatkowo dało się zaobserwować u członków grupy przepływ zwarty, czas wolny, wielokierunkowość, ciężar lekki wg Systemu LMA. Pod wpływem zastosowanych interwencji dało się zauważyć jak ciała poszczególnych członków grupy rozluźniają się, a ich klatka piersiowa otwiera. Obserwowałam również uruchamianie przez uczestników głębokich mięśni brzucha i osadzanie się w przestrzeni terapeutycznej. Jednocześnie widziałam jak stają się uważni na swoje ciało i ruch, co z kolei przekładało się na ich poczucie pewności siebie oraz obniżenie poziomu lęku i napięcia.

Wnioski: Pomimo tego, że prowadzenie procesu grupowego w społeczności półotwartej nie jest sytuacją komfortową dla psychoterapeuty oraz pacjentów, ze względu na trudność w odnalezieniu poczucia bezpieczeństwa oraz naturalnie pojawiający się opór przed przywiązaniem się, sesje wydają się być bardzo pomocne w integrowaniu społeczności pacjentów oraz radzeniu sobie z napięciem wewnętrznym każdego z jej członków.

Słowa kluczowe: psychoterapia, DMT, LMA, grupa terapeutyczna

\section{Introduction}

Dance and movement psychotherapy or DMT or DMP is an approach that assumes that the body and mind are inseparable and that movement reflects the emotional state of the person moving. The aim of DMT is to support development through changes in movement to lead to changes in the psyche [1]. The most important element is the therapeutic process, which is supposed to lead to the removal or reduction of the severity of the disease symptoms [2].

The British Association for Dance and Movement Psychotherapy has produced an elaborate definition which reads: "Dance and Movement Psychotherapy is the psychotherapeutic use of expressive movement and dance through which a person can engage in a process leading to personal integration and development. It is based on the principle that there is a connection between emotions and movement, by exploring a more varied range of movement clients have the opportunity to experience greater balance, with an increase in spontaneity and adaptability. Through movement and dance, the inner world of the person becomes clearer, and in dancing together a relationship becomes visible. The DMT therapist creates conditions where emotions can be safely expressed and communicated and can meet with acceptance" [3].

"Dance, unlike other art forms, exists simultaneously in time and space, unites creator and work, and serves to embody and express through the body an inner experience" [4]. The use of body movement as a therapeutic tool has been known for a long time in the history of dance. It served as a form of communicating emotions, built a sense of collective identity, was part of rites of passage, helped in life crises, periods of change [1].

Sigmund Freud already noted the connection between the body and emotions. According to him, conflict was supposed to be the domain of the ego, which is "first and foremost the bodily ego" [5]. However, the greatest influence on noticing the human being as a whole, including the body, had Alfred Adler, Wilhelm Reich (character analysis of the patient on the basis of body observation, the concept of "body armour", development of specific movement exercises) and Carl Gustav Jung (theory of active imagination) [1].

DMT draws on ideas of modern dance (dating back to the early 20th century) and psychotherapy theory. Initially practised by dancers and resembling dance, it evolved over time and was recognised as a strand of psychotherapy [6]. In the 1940s, dance and movement therapy was conducted exclusively for people with verbalisation difficulties, i.e. psychotic and autistic patients, and sessions were held in psychiatric hospitals. It was not until the 1950s that some therapists opened up to a group of neurotic clients. The desire to explore the nature of personality, and the influence of movement on the human personality, led many DMT precursors (such as Marian Chace, Trudi Schoop, Mary Whitehouse, Blanche Evan, Liljan Espenak) to train in the fields of psychology and psychotherapy, and then to integrate theory with DMT practice. Currently, psychologists rather than dancers are trained in this method. It is common to find that no music is used during sessions, dance is seen broadly - as movement, breath, or functional movement, and improvisation is mostly used [1].

DMT (like other forms of artepsychotherapy, psychodrama, Gestalt therapy, psychomotor therapy and bioenergetics) can be classified as an action-oriented therapy stream [5]. It provides an opportunity to identify emotions and experiences through verbal and psychomotor interventions. It provides opportunities to express and work through emotions and thoughts on many levels. The aim is to integrate body and mind using projective methods. The concept is to contribute to the awareness of hidden emotions and unconscious contents by involving the body. The psychotherapist has the task to give structure to the uncovered contents by using theatrical or artistic techniques [1].

In dance and movement therapy, the most important means of expression is movement integrated with verbalisation. In movement the therapeutic relationship is built up. Movement provides a framework for working 
with body image and personality development. Also in movement the source of change is searched for [1]. However, an additional element of dance and movement psychotherapy is verbalisation as an interpretation and consolidation of change [7]. Hence, verbal interventions are used both as a discussion of movement processes and used during the movement process.

Dance and movement therapy uses the creative process, movement metaphors and analysis and observation of movement. It also uses group process theory. According to D. W. Winnicott, we can only discover the self by being creative, and the different DMT approaches are linked by the use of movement metaphor [8]. DMT psychotherapists, in their work, use a complex system of movement observation (LMA), which helps to understand patients' body language. The LMA system is based on Rudolf Laban's movement analysis and was developed by Warren Lamb, Judith Kastenberg and Irmgaard Bartenieff [9]. LMA focuses on the observation of three areas: Body, Effort, and Shape/Space. When observing the Body, the therapist focuses, among other things, on noticing which parts of the body are in motion and which are at rest, whether there is fragmentation of movement, what is the use of the kinesphere, what is the patient's relationship to the ground [8]. In the Effort area attention is paid to: Weight (expresses intention), Space (relates to attention), Time (relates to decision making) and Flow (expresses emotions and relationships) [8]. The Shape/Space category was developed by Warren Lamb and within it he distinguished: Shape Flow (related to early developmental patterns), Targeting (goal-directed movement), Shaping (fitting shape to environment). In addition, the rhythm of movement is observed based on a system developed by Judith Kastenberg, who identified 10 developmental rhythms and assigned them to specific ages.

Dance and movement therapy can be aimed at people who have problems with verbal communication. It is a form of treatment aimed at patients suffering from autism, schizophrenia, as well as people who have suffered traumatic experiences in the pre-verbal period. DMT is also effective for people who have been subjected to such difficult experiences that the patient is unable to put them into words. This method is particularly helpful for patients with a disturbed self-image or after a trauma that has affected the body [1].

It is important to distinguish between dance and movement psychotherapy and choreotherapy (or therapeutic dance). Choreotherapy is a complementary form of other therapeutic treatment, while DMT is included in the stream of action-oriented therapies. The use of DMT requires completion of a four-year training, which is comprehensive and its standards are defined by the Polish Association of Dance and Movement Psychotherapy. The Association also maintains a register of certified psychotherapists, requires regular supervision and continuing education from its members and these requirements are included in the Code of Ethics [1].

\section{Material and method}

The aim of this study is to describe a case series of patients treated at the General Psychiatric Ward who participated in group sessions of dance and movement psychotherapy (DMT) and to analyse the impact of psychotherapy on their healing process.

In 2019, patients of the General Psychiatric Ward were included in dance and movement psychotherapy (DMT) sessions. The sessions were held once a week from October 2019 to December 2019 and lasted 1h and $10 \mathrm{~min}$. The ward operates on a 24 -hour basis. Due to the characteristics of the 24-hour general psychiatric ward and the high turnover of patients, the group was semiopen.

Ward accommodates people in mental crisis as a consequence of decompensation in the course of their illness. The Ward is dedicated to patients with a diagnosis of paranoid schizophrenia, bipolar affective disorder and recurrent depressive disorder. All patients in the Ward are receiving pharmacotherapy. Some of them had meetings with psychologists, which most often took the form of supportive therapy. During 3 months, 12 patients participated in the sessions on a rotational basis. Patients were reluctant to attend dance and movement psychotherapy sessions.

When work with the group began, there were 6 patients in the Ward. The core of the group consisted of five patients.

\section{- Patient 1:}

Mr T., a young man who has been treated for paranoid schizophrenia for many years. During his current stay, the diagnosis of the illness was changed to personality disorder. Observing Mr. T., it was hard to resist the feeling that living with the idea that he suffers from schizophrenia has taken a heavy toll on him. Mr T. looked and moved like a mentally ill person. His affect was blunted, his face amimic, and he did not make verbal or eye contact spontaneously. He presented symptoms similar to the axial symptoms of schizophrenia: apathy, anhedonia, flat affect. However, the patient did not present ambivalence, alogia, symptoms of disorganized thinking or cognitive functions $[10,11]$. He usually sat hunched over, moved with small steps, had tense shoulders but loose, seemingly inert forearms and wrists. He also met the criteria for dynamic deficits (excessive fatigue, increased need for sleep, decreased energy and endurance) according to BSABS [11]. Every time he entered the therapy room, he 
moved like a sick person, whereas when he left the therapy room, his body was more integrated. Despite the changes observed in him, he often questioned the effectiveness of psychotherapeutic interventions.

- Patient 2:

Mr. A., an elderly man who came to the Ward due to dementia, met the diagnostic criteria according to ICD-10, i.e. disorders of memory, thinking, orientation, comprehension, counting learning ability, language and judgment [12]. Due to his clear consciousness, at first contact it was difficult to realize that he needed care for basic life activities. Only a longer conversation showed inadequacy and shallowness of speech. Mr A. moved with small steps. He was bent over in the thoracic spine and upright and stiff in the lumbar spine. His shoulders were raised and tense, his forearms and hands were loose.

- Patient 3:

Mrs. B., a middle-aged patient, in the first trimester of pregnancy. She came to the Clinic with a significant sense of anxiety about her unborn child. During the following sessions Mrs. B. presented herself as a passive-aggressive person who gets into conflicts with other patients. Mrs. B. had tense shoulders and loose hands and wrists. Her movement was dominated by swaying.

- Patient 4:

Mrs. M., who was diagnosed with a depressive episode, was a patient with a sense of having little influence on her surroundings. She often needed strengthening in self-esteem. She moved with tense shoulders and arms.

- Patient 5:

From the middle of the session, Mrs. Be., who had been hospitalized for a moderate depressive episode, joined the group. She was characterised by a great sense of control and an independent interruption of the therapeutic experience. Watching her in movement one had the impression that she was trying to catch nonexistent threads, suspended somewhere around her.

The others attended one or two sessions.

A common element in movement that could be observed in most people in this group was tense, stiff shoulders and free forearms and/or hands. Additionally, compact flow, free time, multidirectionality, light weight, tense body, ball or pin shape could be observed in the group members [13]. This was also reflected in the feeling in the body and the movement of the session leader. During one supervision, it was noticed that the session notes were made in a small, hurried handwriting. This observation was associated with tense arms and shoulders in most of the group participants. According to the Laban-Bartenieff Movement System (LBMS), flow indicates emotions and relationships [8], and the compact flow of the group members indicated their difficulty in spontaneously interacting with other people. Time according to the
LBMS relates to decision-making [8], and leisure time may indicate difficulties in this area and the postponement of important tasks, which in turn, in patients of the General Psychiatric Ward, may be related to the need to postpone important matters for the future due to a mental crisis and the need for hospitalisation. Space relates to attention [8], and multidirectionality in this area may indicate difficulties in concentration and goal pursuit. In contrast, weight, seen in movement, expresses intention [8], and light weight indicated difficulties in decision-making and a sense of lack of influence over one's life. This theme was often brought up by group members during verbalisation. It was also linked to movement, in which inert, powerless hands were visible, expressing a sense of powerlessness in the patients of Ward.

It was decided to work with the group using playful experiences, following the theory that creative activity helps to find the self [14]. One of the interventions, was to play with balloons. Each participant of the group was given a balloon and had the task to bounce it with different parts of the body. During this experience it could be observed how the bodies of the different group members relaxed and their chests opened. In turn, seeing a dominant light weight, an improvisation was led titled "At the same time it was possible to observe how the group members became aware of the fact that their bodies were loosening up and their chests were opening up. At the same time it was possible to observe how they became attentive to their body and movement [15]".

Initially, during the sessions with this group, the leader felt a lot of anxiety, fear, tension within herself. They were looking for different reasons that could trigger this. Only during the 5th session, the group was asked if they felt tense because the psychotherapist felt tension in their body. A negative answer was heard. However, when relaxation exercises were done with the patients [15] and the researcher felt the relaxation, the patients started to talk about anxiety, uncertainty and fear. The situation described was interpreted as the psychotherapist feeling the group members' paranoid fear of injury, destruction, frustration and disintegration, which are characteristic of the initial stage of the group process, the dependency phase [16]. Their tense bodies blocked them from accessing feelings of anxiety, and when given the opportunity to relax, they accessed these unpleasant feelings. Additionally, by asking if they felt tension in their bodies, the anxiety that the researcher was dealing with was given back to them, and the patients were able to start working on this feeling. One of the interventions that was introduced was looking for your safe place in the room and marking your safe space and kinesphere there. Mr. T. left during the experience and only returned at the end of the session. Mrs. B. and Mrs. M. sat with their backs to the wall 
and only marked their safe space at the front. This gave the researchers a clue as to how the group could continue to work, sensitising them to the stimuli coming from behind them. Mr. A. could not find a safe space. He also did not mark the kinesphere. By the end of the task he was pacing around the room and despite repeatedly mentioning that the time of the experience ends at the end of the music piece, he was unable to settle in one place. This was linked to his situation, which had changed significantly in a short space of time. He was awaiting placement in a Nursing Home, so it was difficult for him to find a place safe for himself being suspended between the old and the new.

The difficulty of the group as a whole was also to find its identity. This was partly due to the fact that, because of the characteristics of the Ward, it was a semiopen group in which it was difficult to find the stability associated with a stable composition of its members. As time went by, more and more people finished the therapeutic process and left the group, while others were admitted to the Clinic and joined the therapeutic sessions. Due to the rotation of patients in the Ward, when the core of the group began to form, someone left the Ward, someone else was admitted, and the group changed its shape. The changing structure made the patients feel a lack of stability in the group, which further exacerbated the anxiety associated with experiencing the first phase of the therapy group [16]. An additional aspect was the patients' individual difficulties. Some people were very self-centered (e.g. Mrs. B., who at the fourth session made an appointment to talk to an individual psychotherapist, or Mrs. D., who after attending the fourth session stated that the DMT therapy did not help her, because she had "too many thoughts" after it), others preferred to identify with the patients of Ward „A" (e.g. Mr. T. at every session repeated that he was to be transferred to Ward „A"). Some patients were in conflict with each other (e.g.: Mrs. B. and Mrs. M. revealed it during the fifth session). Already from the first session it was observed that patients avoided not only physical contact with each other, but also eye contact. The group participants tried to unfriend each other. Despite a clearly stated therapy group rule about confidentiality (the therapy group rules were posted on the wall in the therapy room for the entire duration of therapy and discussed every time someone new came into the group), they were mostly quite secretive. At the same time, a high desire for self-presentation was observed, which many times was inadequate to the situation.

Over time, as more people completed the therapeutic process and left the group, a problem was noticed that most of the patients struggled with. It was the difficulty of saying goodbye and finishing the stages. This topic was raised several times in the group, but each time the leader had the impression that it concerned people who were no longer in therapy.

By the time the group sessions were completed in Ward, the patients who were the core of the group had left the Ward. During the final sessions the work was performed with a group of people who were in a phase of getting to know each other. They did not talk much about themselves, a strong fear of self-discovery and of merging with the group was evident in their expressions and movements [16]. During this period, techniques were used to support the integration of group members, such as moving and stopping together, responding in movement to the others. In addition, the role of the psychotherapist was to maintain a sense of constancy of the group as one element that remained constant.

\section{Discussion}

The characteristics of the General Psychiatric Ward enforce the semi-open nature of the therapy group. This is in part inconsistent with the principles of the group psychotherapy setting [16], as it interferes with the patients' ability to integrate and find trust and a sense of security. Additionally, resistance to attachment naturally arises in group members. However, it was possible to find space for patients to explore this topic. The situation significantly highlighted the feeling of lack of influence on the environment, which was the therapeutic theme of each group member. It was thus possible to work on this difficulty and to find parallels in everyday life outside the Ward.

By having patients end the therapeutic process at different stages and at different times, the difficulty of saying goodbye, and thus ending successive stages, was highlighted. This issue was taken up repeatedly during the group sessions, and the patients had the opportunity to explore this topic for themselves.

The semi-open group had another advantage. In a team where members rotate, they have the opportunity to try themselves out in different group roles and to see if they react similarly in each personnel arrangement or what makes their perspective on the group change.

Unfortunately, the patients of Ward did not have the opportunity to experience all stages of the development of the therapy group [16]. They experienced the orientation phase and the confrontation and exploration of differences phase. Not everyone had the opportunity to experience the phase of in-depth exploration of problems on an individual level. On the other hand, in the semi-open group discussed above, the final phase, that of ending psychotherapy, did not occur.

\section{Conclusions}

Although conducting the group process in a semiopen community is not a comfortable situation for the 
psychotherapist and the patients due to the difficulty of finding a sense of security and the naturally occurring resistance to attachment, the sessions seem to be very helpful in integrating the patient community and dealing with the inner tensions of each member. During the DMT sessions, the group members had the opportunity to expand their motor ranges and discuss the problems they carried within themselves that caused them a lot of fear and anxiety, which supported the treatment process taking place in Ward.

\section{Wstęp}

Psychoterapia tańcem i ruchem czyli DMT lub DMP to nurt, który zakłada, że ciało i umysł są nierozłączne oraz że ruch odzwierciedla stan emocjonalny poruszającej się osoby. Celem DMT jest wspomaganie rozwoju poprzez zmiany w ruchu, które mają prowadzić do zmian w psychice [1]. Najistotniejszym elementem jest proces leczniczy, który ma doprowadzić do usunięcia lub zmniejszenia nasilenia objawów chorobowych [2].

Brytyjskie Stowarzyszenie Terapii Tańcem i Ruchem (Association for Dance and Movement Psychotherapy) stworzyło rozbudowaną definicję, która brzmi: „Psychoterapia tańcem i ruchem jest psychoterapeutycznym wykorzystaniem ekspresyjnego ruchu i tańca, poprzez który człowiek może zaangażować się $\mathrm{w}$ proces prowadzący do osobistej integracji i rozwoju. Oparta jest na zasadzie, że istnieje związek między emocjami a ruchem, poprzez eksplorowanie bardziej zróżnicowanego zakresu ruchów klienci mają zaś możliwość doświadczania większej równowagi, przy jednoczesnym wzroście spontaniczności i zdolności adaptacyjnych. Poprzez ruch i taniec wewnętrzny świat osoby staje się bardziej zrozumiały, a we wspólnym tańcu widoczna staje się relacja. Terapeuta DMT stwarza warunki, w których emocje mogą być w bezpieczny sposób wyrażone i przekazane i mogą się spotkać z akceptacją" [3].

„Taniec w odróżnieniu od innych form sztuki istnieje jednocześnie w czasie i przestrzeni, jednoczy twórcę oraz dzieło, służy ucieleśnieniu i wyrażeniu poprzez ciało wewnętrznego doświadczenia" [4]. Wykorzystanie ruchu ciała jako narzędzia terapeutycznego znane jest od dawna w historii tańca. Służył jako forma komunikowania emocji, budował poczucie tożsamości zbiorowej, był częścią rytuałów przejścia, pomagał w kryzysach życiowych, okresach zmian [1].

\section{Metoda}

Już Zygmunt Freud zauważał związek między ciałem a emocjami. Wg niego konflikt miał być domeną ego, które jest „po pierwsze i najważniejsze ego cielesnym” [5]. Jednak największy wpływ na zauważenie człowieka jako całości, włącznie z ciałem, mieli Alfred Adler, Wilhelm Reich (analiza charakterologiczna pacjenta na podstawie obserwacji ciała, pojęcie „zbroi ciała”, opracowanie konkretnych ćwiczeń ruchowych) i Carl Gustav Jung (teoria aktywnej wyobraźni) [1].

DMT czerpie z idei tańca współczesnego (sięgającego początków XX wieku) oraz teorii psychoterapii. Początkowo była praktykowana przez tancerzy i przypominała taniec, z czasem ewoluowała i została uznana za nurt psychoterapii [6]. W latach czterdziestych XX w. terapia tańcem i ruchem była prowadzona wyłącznie dla osób mających kłopoty z werbalizacją, czyli dla pacjentów psychotycznych i autystycznych, a sesje odbywały się w szpitalach psychiatrycznych. Dopiero w latach pięćdziesiątych XX w. część terapeutów otworzyła się na grupę klientów neurotycznych. Chęć eksplorowania natury osobowości oraz wpływu ruchu na osobowość człowieka, sprawiło, że wielu prekursorów DMT (takich jak: Marian Chace, Trudi Schoop, Mary Whitehouse, Blanche Evan, Liljan Espenak) zaczęło doszkalać się w dziedzinach psychologii i psychoterapii, a następnie integrować teorię z praktyką DMT. Aktualnie w tej metodzie szkolą się raczej psycholodzy niż tancerze. Często można spotkać się z tym, że podczas sesji nie używa się muzyki, taniec postrzegany jest szeroko - jako ruch, oddech, czy ruch funkcjonalny, w większości stosuje się improwizację [1].

DMT (tak jak inne formy artepsychoterapii, psychodrama, terapia Gestalt, terapia psychomotoryczna i bioenergetyka) można zaliczyć do nurtu terapii zorientowanych na działanie [5]. Daje możliwość rozpoznawania emocji i przeżyć poprzez interwencje werbalne oraz psychomotoryczne. Dostarcza możliwości wyrażenia i przepracowania emocji oraz myśli na wielu poziomach. Celem jest integracja ciała i umysłu wykorzystując metody projekcyjne. Koncepcją jest przyczynianie się do uświadomienia sobie skrywanych emocji i nieświadomych treści, poprzez zaangażowanie ciała. Psychoterapeuta ma za zadanie nadać strukturę odkrytym treściom wykorzystując techniki teatralne lub artystyczne [1].

W terapii tańcem i ruchem najważniejszym środkiem ekspresji jest ruch zintegrowany z werbalizacją. W ruchu budowana jest relacja terapeutyczna. Ruch dostarcza ram do pracy z obrazem ciała oraz rozwoju osobowości. Również w ruchu poszukuje się źródła zmian [1]. Jednak dodatkowym elementem psychoterapii tańcem i ruchem jest werbalizacja jako zinterpretowanie i utrwalenie zmian [7]. Stąd interwencje werbalne są stosowane 
zarówno jako omówienie procesów ruchowych jak i używane w trakcie procesu ruchowego.

Terapia tańcem i ruchem wykorzystuje proces twórczy, metafory ruchowe oraz analizę i obserwację ruchu. Posługuje się również teorią procesu grupowego. Wg D. W. Winnicotta możemy odkrywać jaźń tylko przez bycie twórczym, a różne podejścia DMT łączy wykorzystanie metafory ruchowej [8]. Psychoterapeuci DMT, w swojej pracy, stosują złożony system obserwacji ruchu (LMA), który pomaga zrozumieć język ciała pacjentów. System LMA oparty jest na analizie ruchu Rudolfa Labana, a został rozwinięty przez Warrena Lamba, Judith Kastenberg oraz Irmgaard Bartenieff [9]. LMA skupia się na obserwacji trzech obszarów: Ciała, Wysiłku, Kształtu/Przestrzeni. Obserwując Ciało, terapeuta skupia się m.in. na zauważeniu które części ciała są w ruchu, a które pozostają w spoczynku, czy występuje fragmentacja ruchu, jakie jest wykorzystanie kinesfery, jaka jest relacja pacjenta z ziemią [8]. W obszarze Wysiłku zwraca się uwagę na: Ciężar (wyraża intencje), Przestrzeń (dotyczy uwagi), Czas (dotyczy podejmowania decyzji) i Przepływ (wyraża emocje i relacje) [8]. Kategorię Kształt/Przestrzeń rozwinął Warren Lamb i w jej ramach wyróżnił: Przepływ Kształtu (związany z wczesnymi wzorcami rozwoju), Ukierunkowanie (ruch skierowany na cel), Kształtowanie (dopasowanie się kształtem do środowiska). Dodatkowo obserwuje się rytm ruchu bazując na systemie opracowanym przez Judith Kastenberg, która wyodrębniła 10 rytmów rozwojowych i przy porządkowała je do określonego wieku.

Terapia tańcem i ruchem może być skierowana do osób, które mają problem z komunikacją werbalną. Jest to forma leczenia skierowana dla pacjentów cierpiących na autyzm, schizofrenię, jak również osób, które doznały traumatycznych przeżyć w okresie prewerbalnym. DMT jest również skuteczne w przypadku osób, które były poddane przeżyciom tak trudnym, że pacjent nie umie ująć ich słowami. Metoda ta jest szczególnie pomocna u pacjentów z zaburzonym obrazem własnego ciała lub po traumie, która dotknęła ciała [1].

Ważne jest, by odróżniać psychoterapię tańcem i ruchem od choreoterapii (inaczej tańca terapeutycznego). Choreoterapia jest formą uzupełniającą inne leczenie terapeutyczne, natomiast DMT zalicza się do nurtu terapii zorientowanych na działanie. Stosowanie DMT wymaga ukończenia czteroletniego szkolenia, które jest kompleksowe, a jego standardy określane są przez Polskie Stowarzyszenie Psychoterapii Tańcem i Ruchem. Stowarzyszenie prowadzi również rejestr certyfikowanych psychoterapeutów, wymaga od swoich członków regularnych superwizji oraz ustawicznego kształcenia się, a wymogi te zostały ujęte w Kodeksie Etycznym [1].
W roku 2019 pacjenci Oddziału Ogólnopsychiatrycznego byli objęci sesjami psychoterapii tańcem i ruchem (DMT). Sesje odbywały się raz w tygodniu od października 2019 r. do grudnia 2019 r. i trwały 1 h i 10 min. Oddział funkcjonuje w trybie całodobowym. Ze względu na charakterystykę pracy oddziału ogólnopsychiatrycznego całodobowego i dużą rotację pacjentów, grupa miała charakter półotwarty.

\section{Materiał}

W Oddziale przebywają osoby będące w kryzysie psychicznym w następstwie dekompensacji w przebiegu choroby. Oddział jest dedykowany pacjentom $\mathrm{z}$ rozpoznaniem schizofrenii paranoidalnej, zaburzenia afektywnego dwubiegunowego oraz zaburzenia depresyjnego nawracającego. Wszyscy pacjenci Oddziału są poddawani farmakoterapii. Część z nich miała spotkania z psychologami, które najczęściej przybierały formę terapii wspierającej. W przeciągu $3 \mathrm{mc}$, w sposób rotacyjny, w sesjach wzięło udział 12 osób. Pacjenci podchodzili $\mathrm{z}$ rezerwą do sesji psychoterapii tańcem i ruchem.

Gdy rozpoczynałam pracę z grupą, w Oddziale przebywało 6 osób. Trzon grupy stanowiło pięciu pacjentów. Pan T., młody mężczyzna, który przez wiele lat leczył się z powodu schizofrenii paranoidalnej; Pan A., starszy mężczyzna, który znalazł się w Oddziale z powodu otępienia; Pani B., pacjentka w średnim wieku, w pierwszym trymestrze ciąży; Pani M. i Pani Be., u których rozpoznano epizod depresyjny umiarkowany.

Panu T., podczas aktualnego pobytu, zmieniono rozpoznanie choroby na zaburzenia osobowości. Obserwując Pana T. nie mogłam oprzeć się poczuciu, że życie z myślą, iż choruje na schizofrenię, odbiło na nim duże piętno. Pan T. wyglądał i poruszał się jak osoba chorująca psychicznie. Jego afekt był blady, twarz amimiczna, spontanicznie nie nawiązywał kontaktu słownego ani wzrokowego. Prezentował objawy podobne do osiowych objawów schizofrenii: apatię, anhedonię, płaski afekt. Jednak u pacjenta nie występowała ambiwalencja, alogia, objawy dezorganizacji myślenia czy funkcji poznawczych [10], [11]. Zazwyczaj siedział zgarbiony, przemieszczał się drobnymi krokami, miał spięte ramiona, ale luźne, jakby bezwładne przedramiona i nadgarstki. Spełniał również kryteria deficytów dynamicznych (nadmierna męczliwość, wzmożona potrzeba snu, spadek energii i wytrzymałości) wg BSABS [11]. Za każdym razem gdy wchodził na salę terapeutyczną, poruszał się jak osoba chora, natomiast gdy z niej wychodził, jego ciało było bardziej zintegrowane. Pomimo zaobserwowanych w nim zmian, często poddawał $\mathrm{w}$ wątpliwość skuteczność oddziaływań psychoterapeutycznych.

Pan A., starszy mężczyzna, który znalazł się 
w Oddziale z powodu otępienia. Spełniał kryteria diagnostyczne wg ICD-10, czyli zaburzenia pamięci, myślenia, orientacji, rozumienia, liczenia zdolności uczenia się, języka i oceny [12]. Ze względu na jasną świadomość, w pierwszym kontakcie trudno było się zorientować, że potrzebuje opieki przy podstawowych czynnościach życiowych. Dopiero dłuższa rozmowa wykazywała nieadekwatność i płytkość wypowiedzi. Pan A. poruszał się małymi kroczkami. Był przygarbiony w odcinku piersiowym kręgosłupa, a wyprostowany i usztywniony w odcinku lędźwiowym. Barki miał uniesione i spięte, przedramiona i dłonie luźne.

Pani B., pacjentka w średnim wieku, w pierwszym trymestrze ciąży. Do Kliniki zgłosiła się ze znacznym poczuciem lęku o nienarodzone dziecko. Podczas kolejnych sesji Pani B. prezentowała się jako osoba bierno-agresywna, która wchodzi w konflikty z innymi pacjentkami. Pani B. miała spięte ramiona oraz luźne dłonie i nadgarstki. W jej ruchu dominowało kołysanie.

Pani M., u której rozpoznano epizod depresyjny, była pacjentką z poczuciem niewielkiego wpływu na swoje otoczenie. Często potrzebowała wzmacniania w poczuciu własnej wartości. Poruszała się mając spięte barki i ramiona.

Od połowy sesji do grupy dołączyła Pani Be. Odznaczało ją duże poczucie kontroli oraz samodzielne przerwanie doświadczeń terapeutycznych. Obserwując ją w ruchu miałam wrażenie, jakby próbowała złapać nieistniejące wątki, zawieszone gdzieś wokół niej. Pozostałe osoby brały udział w jednej lub dwóch sesjach.

\section{Dyskusja}

Wspólny element w ruchu, który można było zaobserwować u większości osób w tej grupie to spięte, sztywne ramiona oraz swobodne przedramiona i/lub dłonie. Dodatkowo dało się zaobserwować u członków grupy przepływ zwarty, czas wolny, wielokierunkowość, ciężar lekki, spięte ciało, kształt kulki lub pinezki [13]. Miało to przełożenie również na moje poczucie w ciele oraz ruch. Podczas jednej z superwizji, zwrócono mi uwagę na to, że moje notatki z sesji są wykonane drobnym, pośpiesznym pismem. Miałam wtedy skojarzenie ze spiętymi ramionami i barkami u większości uczestników. Wg analizy ruchu Laban-Bartenieff (Laban Bartenieff Movement System) przepływ wskazuje na emocje i relacje [8], a przepływ zwarty członków grupy wskazywał na ich trudności w spontanicznym wchodzeniu w relacje $\mathrm{z}$ innymi ludźmi. Czas wg LBMS dotyczy podejmowania decyzji [8], a czas wolny może wskazywać na trudności w tym zakresie i odraczanie ważnych zadań, co z kolei u pacjentów Oddziału Ogólnopsychiatrycznego może wiązać się z koniecznością odłożenia ważnych spraw na przyszłość spowodowaną kryzysem psychicznym i koniecznością hospitalizacji. Przestrzeń dotyczy uwagi [8], a wielokierunkowość w tym zakresie może wskazywać na trudności w koncentracji i dążeniu do celu. Z kolei ciężar widoczny w ruchu wyraża intencje [8], a ciężar lekki wskazywał na trudności w podejmowaniu decyzji i poczucie braku wpływu na swoje życie. Ten temat często był poruszany przez członków grupy podczas werbalizacji. Łączył się również z ruchem, w którym widoczne były bezwładne, bezsilne ręce, wyrażające poczucie niemocy u pacjentów Oddziału.

Postanowiłam podjąć pracę $\mathrm{z}$ grupą stosując doświadczenia $\mathrm{w}$ formie zabawy, podążając za teorią, że twórcza aktywność pomaga $\mathrm{w}$ odnalezieniu self [14]. Jedną z interwencji, była zabawa balonami. Każdy uczestnik grupy otrzymał swojego balona i miał za zadanie odbijać go różnymi częściami ciała. W trakcie tego doświadczenia obserwowałam, jak ciała poszczególnych członków grupy rozluźniają się, a ich klatka piersiowa otwiera. Z kolei widząc dominujący ciężar lekki, poprowadziłam improwizację pt. „pozostawianie swojego śladu", podczas której obserwowałam uruchamianie przez uczestników ciężaru ciężkiego i osadzanie się w przestrzeni terapeutycznej. Jednocześnie widziałam jak stają się uważni na swoje ciało i ruch [15].

Początkowo podczas sesji z tą grupą czułam w sobie dużo niepokoju, lęku, napięcia. Szukałam różnych powodów, które mogłyby to wywoływać. Dopiero podczas 5 sesji zapytałam grupę, czy czują się spięci, ponieważ ja czuję napięcie w ciele. Usłyszałam odpowiedź przeczącą. Jednak gdy zrobiłam $\mathrm{z}$ nimi ćwiczenia relaksacyjne [15] i sama poczułam rozluźnienie, to pacjenci zaczęli mówić o niepokoju, niepewności i lęku. Wtedy zdałam sobie sprawę, że odczuwałam paranoiczny lęk członków grupy przed zranieniem, zniszczeniem, frustracją i rozpadem, które są charakterystyczne dla stadium początkowego procesu grupowego, czyli fazy zależności [16]. Ich spięte ciała blokowały im dostęp do uczucia lęku, a gdy mieli możliwość rozluźnienia, uzyskali dostęp do tych nieprzyjemnych odczuć. Dodatkowo zadając pytanie, czy czują napięcie $\mathrm{w}$ ciele, oddałam im lęk, z którym sama się zmagałam. Równocześnie stałam się wolna od napięcia uczestników grupy, natomiast pacjenci mogli zacząć pracę nad tym uczuciem. Jedną z interwencji, którą wprowadziłam, było szukanie swojego bezpiecznego miejsca w sali oraz zaznaczanie tam swojej bezpiecznej przestrzeni i kinesfery. Pan T. wyszedł w trakcie doświadczenia i wrócił dopiero pod koniec sesji. Pani B. i Pani M. usiadły tyłem do ściany, a swoją bezpieczną przestrzeń zaznaczyły jedynie $\mathrm{z}$ przodu. Dało mi to wskazówkę, jak mogłabym dalej pracować z grupą, uwrażliwiając ich na bodźce dochodzące zza ich pleców. Pan A. nie mógł znaleźć bezpiecznego miejsca. Nie zaznaczył również kinesfery. Do końca zadania 
krążył po sali i pomimo wielokrotnego wspominania, że czas doświadczenia kończy się wraz z końcem utworu muzycznego, nie był $\mathrm{w}$ stanie osadzić się $\mathrm{w}$ jednym miejscu. Wiążę to z tym, że jego sytuacja, znacznie się zmieniła w krótkim czasie. Oczekiwał on na umieszczenie w Domu Pomocy Społecznej, więc trudno było mu odnaleźć miejsce bezpieczne dla siebie będąc zawieszony między starym a nowym.

Trudnością grupy jako całości było również odnalezienie swojej tożsamości. Część pacjentów była bardzo skoncentrowana na sobie (np. Pani B., która na czas czwartej sesji umówiła się na rozmowę z psychoterapeutą indywidualnym lub Pani D., która wzięła udział jedynie w czwartej sesji, po czym stwierdziła, że sesja DMT jej nie służyła, bo miała po niej „za dużo przemyśleń”), inni woleli utożsamiać się z pacjentami Oddziału A (np.: Pan T. na każdych zajęciach powtarzał, że ma być przenoszony do Oddziału A). Część pacjentów była ze sobą w konflikcie (np.: Pani B. i Pani M. ujawniły go podczas sesji piątej). Potwierdzeniem mojego poczucia było to, że już na pierwszej sesji zaobserwowałam, że pacjenci unikają nie tylko kontaktu fizycznego między sobą, ale również wzrokowego. Dodatkowo $\mathrm{z}$ powodu rotacji pacjentów w Oddziale, gdy zaczynał się tworzyć trzon grupy, ktoś opuszczał Oddział, ktoś inny był przyjmowany, a grupa zmieniała swój kształt. Zmieniająca się struktura sprawiała, że pacjenci odczuwali brak stabilności w grupie, co dodatkowo nasilało lęk związany z przeżywaną pierwszą fazą grupy terapeutycznej [16]. Uczestnicy grupy próbowali się ze sobą nie zaprzyjaźnić. Dodatkowo, pomimo jasno określonej zasady grupy terapeutycznej o poufności (zasady grupy terapeutycznej były wywieszone na ścianie $w$ sali terapii przez cały czas trwania terapii oraz omawiana za każdym razem, gdy w grupie pojawiał się ktoś nowy), w większości byli dość skryci. Jednocześnie obserwowałam dużą chęć autoprezentacji, która wielokrotnie była nieadekwatna do sytuacji. Grupa półotwarta miała również pewną zaletę. W zespole, w którym członkowie ulegają rotacji, mają oni możliwość wypróbowania się $\mathrm{w}$ różnych rolach grupowych oraz sprawdzenia, czy w każdym układzie personalnym reagują podobnie lub co sprawia, że ich spojrzenie na grupę zmienia się.

Z biegiem czasu, gdy kolejne osoby kończyły proces terapeutyczny i opuszczały grupę, zauważyłam problem, z którym zmagała się większość pacjentów. Była to trudność w pożegnaniu się i kończeniu kolejnych etapów. Podejmowałam ten temat wielokrotnie na grupie, jednak za każdym razem miałam wrażenie, że dotyczy on osób, których już nie ma w terapii.

Zanim zakończyłam praktyki osoby, które były trzonem grupy, opuściły Oddział. Podczas końcowych sesji pracowałam z grupą osób, które były w fazie poznawania się. Niewiele mówiły o sobie, w wypowiedziach i ruchu widoczny był silny lęk przed odkryciem się oraz zlaniem z grupą [16]. W tym okresie stosowałam techniki wspierające integrację członków grupy, takie jak wspólne poruszanie się i zatrzymywanie, reagowanie w ruch na pozostałych osób. Dodatkowo moją rolą było utrzymanie poczucia stałości grupy, jako jeden z elementów, który pozostał niezmienny.

\section{Wnioski}

Pomimo tego, że prowadzenie procesu grupowego w społeczności półotwartej nie jest sytuacją komfortową dla psychoterapeuty oraz pacjentów, ze względu na trudność w odnalezieniu poczucia bezpieczeństwa oraz naturalnie pojawiający się opór przed przywiązaniem się, sesje wydają się być bardzo pomocne w integrowaniu społeczności pacjentów oraz radzeniu sobie z napięciem wewnętrznym każdego z jej członków. Mam poczucie, że podczas sesji DMT członkowie grupy mieli możliwość poszerzenia swoich zakresów ruchowych oraz omówienie problemów, które nosili w sobie, a które powodowały w nich duży lęk i niepokój, co wspomogło proces leczenia odbywający się w Oddziale.

\section{Conflict of interest}

The authors have declared no conflict of interest.

\section{References:}

1. Pędzich, Z. (ed.), Psychotherapy with dance and movement. Individual and group therapy. Sopot: Gdańskie Wydawnictwo Psychologiczne, 2014

2. Czubała, J. C., Czynniki leczące w psychoterapii, Warszawa: Wydawnictwo Naukowe PWN, 1997

3. Payne, H. (red.), Dance movement therapy: Theory, reasearch and practice (wyd. 2). London - New York: Routledge - Taylor \& Francis Group, 1992

4. Sachs, C., World history of the dance. New York: W. W. Norton \& Co, 1965

5. Levy, F. J., Dance/movement therapy: A headling art. Reston: National Dance Assiciacion, American Alliance for Health, Physical Education, Recreation, and Dance, 1992

6. Payne, H., Supervision of dance movement psychotherapy: A practitioners guide, London - New York: Routledge, 2008

7. Siegell, E. V., Psychoanalytic dance therapy: The Bridge between psyche and soma, American Journal of Dance Therapy, 17(2), 115-128, 1995

8. Meekums, B. , Dance movement therapy. A creative psychoterapeutic approach. London: Sage Publications, 2002

9. Winnicott, D. W., Children and their mothers, Transl. M. Halaba. Warsaw: W.A.B., 1994

10. Galecki P., Szulc A., Psychiatry, edra Urban \& Partner, Wroclaw 2018: 160-161

11. Pużyński St., Rybakowski J., Wciórka J., Psychiatria tom 2 Psychiatria kliniczna, wyd. Elsevier Urban \& Partner, Wrocław, 2011: 233-238

12. ICD-10 Classification of Mental and Behavioural Disorders, University Medical Publishing House "Vesalius", Krakow- 
Warsaw, 2000: 50-54

13. Newlove J., Dalby J., Laban for all - Polish translation, Kined Publishers, Warsaw, 2011: 121-140

14. Winnicott D.W., Play and reality, Imago Publishers, Gdańsk, 2011: 82-96

15. Barbara A., Applications of Laban Movement Analysis: An Integrated Approach to Voice, Speech and Movement Training for Actors, Journal of Laban Movement Studies, New York, 2008

16. Yalom I., Group Psychotherapy - Theory and Practice, Jagiellonian University, Krakow, 2006

\section{Corresponding author}

Ewelina Drzał

I Department of Psychiatry, Psychotherapy and Early Intervention, Medical University of Lublin, Poland e-mail: ewelinadrzal@umlub.pl

Otrzymano: 25.03 .2021

Zrecenzowano: 26.03.2021, 29.03.2021

Przyjęto do druku: 15.06.2021 